\title{
Thermal challenge of the microcirculation in patients after cardiac surgery
}

\author{
D Orbegozo Cortes ${ }^{1 *}$, G Stringari ${ }^{1}$, R Damazio ${ }^{1}$, D De Backer ${ }^{1}$, J-L Vincent ${ }^{1}$, J Creteur ${ }^{2}$ \\ From ESICM LIVES 2015 \\ Berlin, Germany. 3-7 October 2015
}

\section{Introduction}

Microcirculatory alterations have been correlated with poorer outcomes in different populations of critically ill patients. A controlled increase in the local skin temperature (thermal challenge) induces vasodilation, which may represent a measure of microcirculation recruitability and can be easily evaluated non-invasively using skin laser Doppler (SLD) (1). We previously demonstrated lower SLD values during thermal challenge in patients with circulatory shock, particularly in non-survivors (2).

\section{Objectives}

The aim of this study was to evaluate whether reduced microcirculatory recruitability could be identified using this technique in patients after cardiac surgery and, if so, whether it was correlated with outcome.

\section{Methods}

We evaluated 28 patients admitted to our department of intensive care after cardiac surgery. A thermostatic SLD probe (Perimed, Sweden) was placed on the proximal anterior forearm to evaluate the skin blood flow (SBF), measured in perfusion units (PU). The probe temperature was set at $37^{\circ} \mathrm{C}$ and we recorded the basal SBF. The temperature was then increased to $43^{\circ} \mathrm{C}$ and the SBF evaluated 9 min later. We calculated the ratio between the two values as an index of capillary recruitment. We compared patients who died or stayed in the ICU for more than 72 hours (COMPLICATED) with those who survived and stayed less than 72 hours in the ICU (CONTROL). All values are presented as median values and interquartile range. We calculated the area under the receiver operating characteristics curve (AUC-ROC) for the SLD ratio $43 / 37^{\circ} \mathrm{C}$ to discriminate between the two groups (COMPLICATED vs CONTROL). All analyses were performed using SPSS 22.0 (IBM, USA).

\section{Results}

The main patient characteristics are shown in Table 1. SBF was similar between groups at $37^{\circ} \mathrm{C}$, but lower at $43^{\circ} \mathrm{C}$

Table 1. Main characteristics of both groups.

\begin{tabular}{llll}
\hline VARIABLE & CONTROL $(\mathbf{n}=\mathbf{1 6})$ & COMPLICATED $(\mathbf{n}=\mathbf{1 2})$ & $\mathbf{P}$ \\
\hline Age (years) & $67 \pm 13$ & $69 \pm 9$ & 0.65 \\
\hline Coronary disease $\mathbf{n}(\%)$ & $8(50)$ & $8(67)$ & 0.68 \\
\hline Pre-surgery left ventricular ejection fraction $\mathbf{( \% )}$ & $60(38-60)$ & $57(28-60)$ & 0.54 \\
\hline Cardiopulmonary bypass time $(\mathbf{m i n})$ & $122(94-130)$ & $127(121-148)$ & 0.31 \\
\hline Hemoglobin (g/dL) & $10.9(10.0-11.5)$ & $9.7(9.3-10.4)$ & 0.09 \\
\hline APACHE II score & $15 \pm 4$ & $21 \pm 6$ & $<0.01$ \\
\hline ICU length of stay (days) & $1.0(0.9-1.9)$ & $6.8(4.2-11.5)$ & $<0.01$ \\
\hline Mortality $\mathbf{n}(\%)$ & $0(0)$ & $3(25)$ & 0.07 \\
\hline
\end{tabular}


Table 2. Hemodynamic and SLD variables.

\begin{tabular}{|c|c|c|c|}
\hline VARIABLE & CONTROL $(n=16)$ & COMPLICATED $(n=12)$ & $\mathbf{P}$ \\
\hline Cardiac index $\left(\mathrm{L} / \mathrm{min} / \mathrm{m}^{2}\right)$ & $2.5(2.0-2.8)(n=7)$ & $1.9(1.8-2.4)(n=12)$ & 0.24 \\
\hline Mean arterial pressure $(\mathrm{mmHg})$ & $79 \pm 8$ & $72 \pm 9$ & 0.04 \\
\hline Central venous pressure $(\mathrm{mmHg})$ & $10(6-12)$ & $11(9-12)$ & 0.83 \\
\hline Lactate $(\mathrm{mEq} / \mathrm{L})$ & $1.4(1.1-2.3)$ & $2.1(1.6-3.0)$ & 0.13 \\
\hline Norepinephrine (mcg/Kg/min) & $0.0(0.0-0.1)$ & $0.2(0.0-0.3)$ & 0.01 \\
\hline Time from ICU admission to SLD test (hours) & $2(1-6)$ & $2(1-15)$ & 0.43 \\
\hline Skin blood flow $37^{\circ} \mathrm{C}(\mathrm{PU})$ & 12.8(10.1-21.7) & 13.0(9.3-19.6) & 0.71 \\
\hline Skin blood flow $43^{\circ} \mathrm{C}(\mathrm{PU})$ & $81.8(47.1-126.3)$ & 38.9(18.0-66.6) & 0.03 \\
\hline Skin blood flow ratio & $5.8(3.2-8.0)$ & $2.9(1.8-3.8)$ & 0.02 \\
\hline
\end{tabular}

in the COMPLICATED than in the CONTROL group (Table 2). The AUC-ROC (CI 95\%) for the SLD ratio was 0.76 (0.58-0.94).

\section{Conclusions}

Patients with a complicated course after cardiac surgery have reduced microcirculatory recruitability as assessed by a non-invasive SLD thermal challenge in the first hours during the ICU stay.

\section{Grant Acknowledgment}

Institutional funds

\section{Authors' details}

${ }^{1}$ Universite Libre de Bruxelles, Hopital Erasme - Intensive Care, Brussels,

Belgium. ${ }^{2}$ Universite Libre de Bruxelles, Brussels, Belgium.

Published: 1 October 2015

\section{References}

1. Kellogg DL Jr, Liu Y, Kosiba IF, O'Donnell D: Role of nitric oxide in the vascular effects of local warming of the skin in humans. $J$ Appl Physiol 1999, 86(4):1185-1190.

2. Stringari, et al: Intensive Care Medicine. 2014, 40(Suppl 1):0155.

\section{Submit your manuscript to a SpringerOpen ${ }^{\circ}$ journal and benefit from:}

- Convenient online submission

- Rigorous peer review

- Immediate publication on acceptance

- Open access: articles freely available online

- High visibility within the field

- Retaining the copyright to your article

Submit your next manuscript at $>$ springeropen.com 